\title{
Evidence On The Effect Of Financial Distress On Type II Audit Errors
}

Paul Wertheim, Abilene Christian University, USA Michael Robinson, Baylor University, USA

\begin{abstract}
A Type II audit error is defined as the failure of an auditor to issue a going concern audit opinion for a client that subsequently declares bankruptcy. Prior research studies have examined audit effectiveness (as measured by Type II audit errors) following the Sarbanes-Oxley Act of 2002, and have generally found an increase in the auditor's likelihood of issuing going-concern audit opinions. This increase in the auditor's likelihood of issuing a going concern opinion postSarbanes-Oxley has been interpreted as an increase in the level of auditor conservatism. [For example, see Geiger et al. (2005) and Fargher and Jiang (2008)]. However, prior studies have often limited their analysis of going-concern audit effectiveness to firms that were already in financial distress, and have also failed to specifically address the extent to which varying levels of financial distress affects the auditor's propensity to issue a going-concern opinion. This raises the main research questions addressed in this study: Does the relationship between financial distress and the probability of receiving a going-concern differ for distressed versus non-distressed firms, and more importantly, to what extent do varying levels of financial distress affect this relationship? We find that the relationship between financial distress and the probability of receiving a going-concern opinion is not linear, as is assumed in prior studies. Rather, we find that the positive relationship between financial distress and going-concern opinions applies only for certain levels of financial distress. These results have implications both in the interpretation of previous auditing research that has incorporated variables for financial distress, as well as implications for the design and interpretation of future research.
\end{abstract}

Keywords: Going Concern; Audit Errors; Financial Distress

\section{INTRODUCTION}

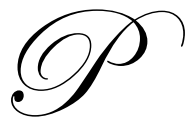

rior accounting research has examined variables associated with the likelihood of auditor's issuing a going-concern audit opinion for corporate clients that subsequently declare bankruptcy. (Failure of the auditor to issue a going concern opinion for a client that subsequently declares bankruptcy is defined as a Type II audit error). As one example, Geiger and Rama (2006) use the following logistic regression model to examine whether Big4 audit firms (as compared to smaller, non-Big4 firms) have significantly lower Type II audit errors:

$\operatorname{PROB}\left(\mathrm{GC}_{\mathrm{bank}}\right)=\beta_{0}+\beta_{1}$ DISTRESS $+\beta_{2} \mathrm{LNSL}+\beta_{3} \mathrm{BLAG}+\beta_{4} \mathrm{RLAG}+\beta_{5} \mathrm{BIGN}$

$$
+\beta_{6} \mathrm{DFLT}+\beta_{7} \mathrm{EXCH}+\mathrm{e}_{\mathrm{gc}}
$$

where:

$\mathrm{GC}_{\mathrm{bank}}=1$ if audit report prior to bankruptcy contained a going-concern opinion, 0 otherwise

DISTRESS $=$ variable measuring level of financial distress

LNSL = natural log of sales (in thousands of dollars)

BLAG = square root of the number of days from the audit report date to the bankruptcy date

RLAG = square root of the number of days from the fiscal year end to the audit report date

BIGN $=1$ if audit firm was from the BigN, 0 otherwise 


$\begin{array}{ll}\text { DFLT } & =1 \text { if firm is in payment default, } 0 \text { otherwise } \\ \text { EXCH } & =1 \text { if firm is listed on NYSE or AMEX, } 0 \text { otherwise } \\ \mathrm{e}_{\mathrm{gc}} & =\text { error term }\end{array}$

The variable of interest in the Geiger and Rama (2006) study was "LNSL," and was used to measure the significance of the relationship between audit firm size and the probability of issuing a going-concern audit opinion. The "DISTRESS" variable was a control variable used to control for the level of financial distress of the firm receiving the audit opinion. For their particular study, Geiger and Rama measured "DISTRESS" using a financial stress score calculated from the Zmijewski (1984) bankruptcy probability model.

Numerous auditing research studies examining going-concern audit opinions have used a similar regression model to that above, and have usually included a control variable measuring the level of "financial distress" faced by the firm when receiving the audit opinion. The inclusion of the control variable is based on research indicating that there is a significant relationship between the level of financial distress and the likelihood of receiving a goingconcern audit opinion. Intuitively, and supported by prior research, is the hypothesis that the higher the level of financial distress, the higher the probability of receiving a going-concern audit opinion. Therefore, a control variable is included in the regression models to control for the level of financial distress so that the effect of other variables of interest can be examined (such as audit firm size in the Geiger and Rama (2006) study).

However, there are limitations in prior research related to their use of a control variable for "financial distress." First, prior studies have used varying measures for "DISTRESS" when constructing their regression models. As stated, Geiger and Rama (2006), as well as many other studies, measure distress using the Zmijewski (1984) bankruptcy probability score. But other studies, using similar regression models, have measured distress using either the Hopwood et al. (1994) bankruptcy probability score or the Altman Z-score, Altman (1968).

In addition, prior studies using a regression model similar to Model 1 above often limit their analysis to samples containing firms already identified as "distressed." For example, Geiger and Rama (2006) eliminate "nonstressed" firms from their sample, after defining a company as "stressed" if it exhibits any of the following characteristics: (1) negative working capital in the year prior to bankruptcy, (2) a loss from operations in any of the three years prior to bankruptcy, (3) negative retained earnings in any of the three years prior to bankruptcy, or, (4) a bottom line loss in any of the three years prior to bankruptcy.

Similarly, Reynolds and Francis (2000), DeFond et al. (2002) and Myers et al. (2008) also examine only "stressed" firms in their samples. In this context, three limitations of these and other prior research studies using similar models are:

1. A potential bias in results based on the variable used to measure financial distress (i.e., a potential difference in results obtained depending on whether financial distress is measured using the Zmijewski (1984) model, the Hopwood et al. (1994) model, or the Altman Z-score,

2. A potential bias in results when the sample excludes firms identified as non-stressed, (i.e., a potential difference in results obtained depending on whether the sample includes or excludes "non-stressed" firms, and,

3. An assumption that the effect of financial distress [i.e., the DISTRESS variable in model (1) above] is linear and applies equally to all levels of financial distress.

Based on these three limitations in prior research, we examine whether there are differences between the three main measures of financial distress, whether the exclusion of "non-stressed" firms affects the results, and whether the relationship between financial distress and going-concern opinions is linear for all levels of financial distress. These results have implications for the interpretation of prior research as well as the design of future audit research. 


\section{FINANCIAL DISTRESS VARIABLES IN PRIOR AUDITING RESEARCH}

Prior research studies in auditing which examine issues related to the auditor's propensity to issue a goingconcern audit opinion typically control for the firm's level of "financial distress." Typically, one of three alternative variables is used as a measure, or proxy, for the level of financial distress; Altman's Z-score, Altman (1968), the Hopwood et al. (1994) bankruptcy probability score, or the Zmijewski (1984) bankruptcy probability score.

Altman Z' Score is calculated as follows: $\mathrm{Z}=.717$ (working capital / total assets) +.847 (retained earnings / total assets) +3.107 (earnings before interest and taxes / total assets) +.420 (stockholder's equity / total liabilities) +.998 (sales / total assets). Auditing studies that have used Altman's Z-score as a measure of financial distress include Reynolds and Francis (2000) and Callaghan et al. (2009).

Zmijewski's (1984) bankruptcy probability score is calculated as follows. First, raw scores are calculated using the components of the Zmizewski et al. (1984) model: intercept of $-4.803-3.599$ (net income / total assets) + 5.406 (total liabilities / total assets) - .100 (current assets / current liabilities). PROB-Z is then calculated as F(Y), where $\mathrm{F}($.$) is the distribution of the standard normal variable. Auditing studies that have used the Zmijewski (1984)$ bankruptcy probability score as a measure of financial distress include Geiger and Rama (2006), Geiger, Ramhunandan and Rama (2006), Robinson (2008), Francis and Krishnan (2002), and Carey, Geiger and O'Connell (2008).

Finally, the Hopwood et al. (1994) bankruptcy probability score is calculated as follows. First, raw scores were calculated using the components of the Hopwood et al. (1994) model: intercept of -7.322 - 15.756 (net income / total assets) +.973 (current assets / sales) -1.677 (current assets / current liabilities) +5.985 (current assets / total assets) -9.145 (cash / total assets) +4.224 (long term debt / total assets) +.214 (natural log of sales). PROB-H is then calculated as $\mathrm{F}(\mathrm{Y})$, where $\mathrm{F}($.) is the distribution of the standard normal variable. Auditing studies that have used the Hopwood et al. (1994) bankruptcy probability score include Myers, Schmidt and Wilkins (2008), Fargher and Jiang (2008), Geiger and Rama (2003), Carey, Kortum and Moroney (2007), and Geiger and Raghunandan (2001).

\section{COMPARISON OF ZMIJEWSKI'S AND HOPWOOD'S BANKRUPTCY PROBABILITY SCORES}

Both Zmijewski (1984) and Hopwood et al. (1994) developed models for estimating the probability of bankruptcy. In neither case were the authors attempting to improve on past bankruptcy-prediction models; the focus of the authors was on methodological issues related to the appropriate estimation of such models. Both of these models use ratios derived from financial statement data. In each study, the authors state that the variables chosen for their models were used because of their performance in other bankruptcy-prediction research.

Zmijewski defined financial distress as "the act of filing a petition for bankruptcy." Thus, a firm that does not file for bankruptcy during a particular year is assumed to be non-distressed during that year. He identified return on assets (net income/total assets), financial leverage (total debt/total assets), and liquidity (current assets/current liabilities) as important dimensions in bankruptcy prediction. Zmijewski developed a probit equation in which the probability of bankruptcy is a function of these three variables. His empirical tests of the model found the choicebased sample bias that exists in prior financial distress research; i.e., that distressed firms are oversampled because researchers first observe the dependent variable and then select a sample based on that knowledge. This bias decreases as the sample selection probability of bankruptcy approaches the population probability, and may be eliminated by the use of appropriate estimation techniques.

Zmijewski also tested for evidence of a potential sample selection bias in prior financial distress research: the likelihood of the sample on which a particular model is estimated is conditional on having complete data. Firms with high bankruptcy probabilities have low probabilities of having complete data. The author first estimated his model ignoring the incomplete data problem and then incorporated the effects of incomplete data into the estimation. $\mathrm{He}$ finds that this refinement yielded few additional insights regarding statistical inferences. Both techniques indicate that the probability of bankruptcy is an increasing function of financial leverage and a decreasing function of return on assets. The liquidity coefficient was not statistically significant. 
Hopwood et al. developed a ratio-based bankruptcy-prediction model to test the relative accuracy of the model's predictions and auditors' opinions. For their model, the authors used six financial ratios that previous research had identified as being a good set of predictors of bankruptcy. The set includes the three ratios used by Zmijewski (Hopwood et al. use long-term debt, rather than total debt, in the leverage ratio), plus current assets/sales, current assets/total assets, and cash/total assets. The six ratios may be viewed either as a subset of the Beaver (1966) and Deakin (1972) models or as the Libby (1975) model plus the long-term debt/total assets leverage ratio. The model also includes the natural log of sales to control for company size.

The sample used by Hopwood et al. to estimate the model was partitioned into stressed and non-stressed firms. The authors used a definition of stress that was based on previous research; a company was classified as stressed if it had (1) negative working capital in the current year, (2) a loss from operations or a bottom line loss in any of the three years prior to bankruptcy, or (3) a retained earnings deficit in Y-3 (where Y-1 is the last financial statement date preceding bankruptcy). The authors' tests support the hypothesis that stressed and non-stressed companies have models with different coefficients. This finding is important because research provides evidence that auditors do not issue going-concern opinions to non-stressed companies, and thus face a different decision problem with stressed companies than with non-stressed companies. Of the six ratios, the return on assets, financial leverage, and liquidity ratios common to the Zmijewski model were found to have the greatest explanatory power for predicting bankruptcy of stressed firms.

In summary, a major difference in the Zmijewski and Hopwood et al. studies is the authors' definition of financial distress. Zmijewski's operational definition is that financial distress $i s$ the act of filing for bankruptcy; Hopwood et al. adopt the more widespread notion that financial distress is a condition, signaled by financial statement data, and may or may not lead to bankruptcy. However, in both studies the authors develop a model to predict bankruptcy based on ratios derived from financial statement data. The three ratios used by Zmijewski are among the six used by Hopwood et al. Significantly, when Zmijewski compared 13 bankruptcy prediction models in the accounting literature, he found that estimated bankruptcy probabilities were generally correlated with one another across the models. Given the high predictive power of the three Zmijewski ratios in the Hopwood et al. model, it is likely that high correlation exists between the estimated probabilities of these two models. If this is true, then one would expect little difference in results regardless of which of the two models model is used in an explanatory setting.

\section{CURRENT HYPOTHESES}

Our study directly addresses the three weaknesses discussed in the introduction as they relate to the common use of a "financial distress" variable in going-concern auditing research. Specifically, we address potential implications of: (1) whether the choice of the variable used to measure financial distress affects the significance of the financial distress variable, (2) whether exclusion of non-stressed firms in the sample affects the significance of the financial distress variable, and, (3) whether the relationship between financial distress and the likelihood of a going-concern opinion is constant for all levels of financial distress.

As a starting point, and based on a consensus in prior research, we assume that the level of financial distress is positively and significantly related to the propensity of an auditor to issue a going concern audit opinion. However, we begin by replicating prior research to test this assumption. This replication of prior research serves as a starting point in the confirmation of the relationship between financial distress and the propensity to issue a goingconcern opinion, and then allows us to address the three main research questions previously listed. Thus, our initial research question is: Does the level of a firm's financial distress affect the auditor's propensity to issue a going concern audit opinion? In null form, the initial hypothesis is:

$\mathbf{H O}_{\mathbf{0}}$ : The level of a firm's financial distress is not related to the auditor's propensity to issue a going concern audit opinion.

As discussed in the previous section, prior going-concern audit research studies have used three main alternative measures of "financial distress." This leads to the first of our three main research questions: Does the selection of the measure for "financial distress" affect whether the variable for financial distress is significant? In 
null form, the first hypothesis is:

H0 1 : The choice of variable used to measure financial distress [the Zmijewski (1984) model, the Hopwood et al. (1994) model, or Altman's Z-score, Altman (1968)], does not affect whether the coefficient for the financial distress variable is significant.

A second limitation of prior research is a potential bias in results when the sample excludes firms identified as non-stressed. This leads to the second of our three research questions: Does the exclusion of "non-stressed" firms in prior research studies affect whether the variable for financial distress is significant? In null form, the second hypothesis is:

$\mathbf{H O}_{2}$ : The choice of whether non-stressed firms are excluded from the sample does not affect whether the coefficient for the financial distress variable is significant.

Finally, a third limitation of prior research is an assumption that the effect of financial distress [i.e., the DISTRESS variable in model (1) above] is linear and applies equally to all levels of financial distress. In null form, the third hypothesis is:

$\mathbf{H O}_{3}$ : There is no difference in the coefficient of the financial distress variable across all levels of financial distress.

These hypotheses will be tested by performing logistic regression analysis as described below.

\section{RESEARCH METHODOLOGY}

Sample Selection. The initial population of firms includes all public companies filing Chapter 11 bankruptcy between January 1, 1997 and December 31, 2009. For all companies, SEC filings were examined to determine the existence/non-existence of a going-concern audit opinion for the fiscal year immediately preceding the year of bankruptcy. Companies filing Chapter 11 bankruptcy are identified from annual issues of the Bankruptcy Yearbook and Almanac, published by New Generation Research, and supplemented by additional firms, if any, listed on the bankruptcydata.com website. For each firm in the sample, SEC filings were examined to determine the firm's auditor, audit report date, financial statement date, and the existence/non-existence of a going concern opinion for the audited financial statements for the fiscal year immediately prior to the fiscal year containing the filing of Chapter 11 bankruptcy. In particular, the SEC filings were examined to determine if the auditor had failed to issue a going concern opinion within the 12 months prior to the bankruptcy filing (a Type II audit error). Financial information obtained from the Compustat database is then used to measure necessary financial variables, including firm size and the level of "financial distress" for each company prior to bankruptcy. Based on prior research, financial distress is measured using the following three alternative variables: Altman's Z'-Score, the Hopwood et al. (1994) bankruptcy probability score, and the Zmijewski (1984) bankruptcy probability score.

Firms were eliminated if SEC filings were not available to determine the firm's auditor, audit report date, financial statement date, financial variables, and the existence/non-existence of a going concern opinion for the audited financial statements for the fiscal year immediately prior to the fiscal year containing the filing of Chapter 11 bankruptcy. Firms were also eliminated if the bankruptcy filing identified during the research period was actually the second bankruptcy filing within a five-year period. Sample selection results are shown in Table 1.

A total of 1826 companies were listed as filing bankruptcy during the research time period of January 1 , 1997 through December 31, 2009. A total of 155 firms were eliminated from the sample for which SEC filings were not available to determine the necessary audit and financial related variables. Also, 49 firms were eliminated from the sample where the bankruptcy filing identified during the research period was actually the second bankruptcy filing within a five-year period. In other words, firms were eliminated if there was a previous bankruptcy filing anytime during a four-year period prior to the year of the bankruptcy filing identified during the research period. These firms were eliminated because any audit opinions issued during the research period would have been influenced by a previously filed bankruptcy. The research question of the current study is to examine each audit 
firm's propensity to issue a going concern opinion prior to a client's bankruptcy, and thus any existence of another previously filed bankruptcy would influence any audit opinion issued subsequent to that bankruptcy. After elimination of these firms, 1622 companies remained in the final sample. Table 1 summarizes these sample selection procedures, including final sample size for each year of the research period $1997-2009$.

Research Design. Hypothesis 0 (our initial research hypothesis) examines the general relationship between financial distress and the propensity to receive a going-concern audit opinion. Accordingly, we test Hypothesis 0 using the following logistic regression model to explain the probability of a Type II audit error:

$$
\begin{aligned}
\operatorname{PROB}\left(\mathrm{GC}_{\mathrm{bank}}\right)= & \beta_{0}+\beta_{1} \text { DISTRESS }+\beta_{2} \mathrm{LNSL}+\beta_{3} \mathrm{BLAG}+\beta_{4} \mathrm{RLAG}+\beta_{5} \mathrm{BIGN} \\
& +\beta_{6} \text { DFLT }+\beta_{7} \mathrm{EXCH}+\mathrm{e}_{\mathrm{gc}}
\end{aligned}
$$

\begin{tabular}{|c|c|}
\hline $\mathrm{GC}_{\text {bank }}$ & $=1$ if audit report prior to bankruptcy contained a going-concern opinion, 0 otherwise \\
\hline DISTRESS & variable measuring the level of financial distress \\
\hline LNSL & $=$ natural $\log$ of sales (in thousands of dollars) \\
\hline BLAG & $=$ square root of the number of days from the audit report date to the bankruptcy date \\
\hline RLAG & square root of the number of days from the fiscal year end to the audit report date \\
\hline BIGN & 1 if audit firm was from the BigN, 0 otherwise \\
\hline DFLT & 1 if firm is in payment default, 0 otherwise \\
\hline $\mathrm{EXCH}$ & 1 if firm is listed on NYSE or AMEX, 0 otherwise \\
\hline$e_{g c}$ & $=$ error term \\
\hline
\end{tabular}

where:

In order to be consistent with prior research, we first perform the analysis on the sample of firms excluding non-stressed firms, consistent with Geiger and Rama (2006), Reynolds and Francis (2000), DeFond et al. (2002) and Myers et al. (2008). We exclude non-stressed firms that did not meet one of the four conditions of "stress" identified by Geiger and Rama (2006). The variables for LNSL, BLAG, RLAG, BIGN, DFLT and EXCH are included to control for other variables that prior research has found to also be potentially related to the propensity to issue a going-concern audit opinion, and are the variables which are also included in the Geiger and Rama (2006) model.

Hypothesis 1 is addressed by duplicating research Model (2) above using each of the following three alternative variables to measure financial distress: (1) the Zmijewski (1984) bankruptcy probability score, (2) the Hopwood et al. (1994) bankruptcy probability score, and (3) Altman's Z-score, Altman (1968).

Hypothesis 2 is addressed by duplicating research Model (2) above for the following sample subsets: (a) the sample of "distressed" firms only, and, (b) the full sample including non-stressed firms. Differences in the coefficients for the "distress" variable are then examined between samples to determine the effect, if any, from sample bias in prior studies that have eliminated "non-stressed" firms from their samples.

Finally, Hypothesis 3 is addressed by examining whether the coefficient for the "distress" variable remains constant for all levels of distress, i.e., whether the relationship is linear. If it is not, then this would indicate that the relationship between financial distress and Type II audit errors depends on the underlying level of financial distress. For example, it is hypothesized that the auditor's propensity to issue a going-concern audit opinion is not affected by the level of financial distress when the level of financial distress is relatively low, and that the level of financial distress is significantly related to going-concern opinions only when the level of financial distress is above a minimum level.

\section{RESULTS}

The logistic regression results related to Hypothesis 0 and Hypothesis 1 are presented in Table 2. Shown are the coefficients (with related Chi-square values in parentheses) for each of the variables in Model 2, including the "DISTRESS" variable measured using each of the three alternative measures for financial distress. 
Table 1: Summary of Sample Selection Procedures: Final Sample Size by Year

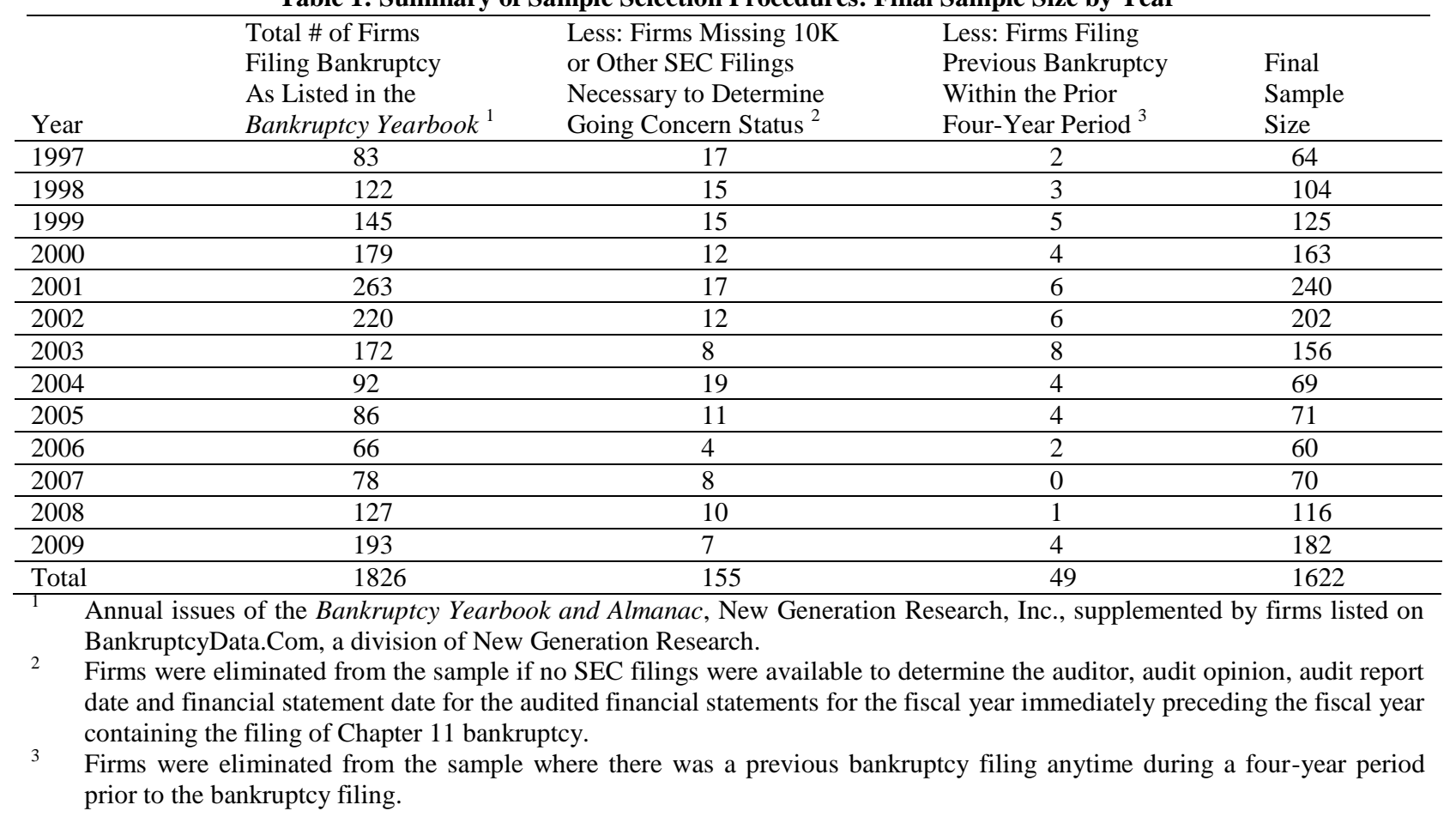

Based on these results, the initial null hypothesis $\left(\mathrm{H}_{0}\right)$ is rejected. There is a positive and significant relationship between the level of financial distress and the probability of receiving a going-concern audit opinion. (The coefficient for DISTRESS using Altman's Z-score is negative because Altman's Z-score is constructed such that a lower score equates to a higher level of financial distress. For the Hopwood and Zmijewski scores, the variables are constructed such that a higher score equates to a higher level of financial distress. Thus, in each case, the higher the level of financial distress, the higher the probability of receiving a going-concern audit opinion). This significant and positive relationship between financial distress and going-concern is consistent with prior audit research. This relationship is significant even after controlling for the effects of firm size (LNSL), auditor size (BIGN), bankruptcy time lag (BLAG), audit reporting time lag (RLAG), default status (DFLT), and exchange listing $(\mathrm{EXCH})$.

Given that the results are consistent for each of the three alternative measures of financial distress, null hypothesis $\mathrm{H}_{1}$ is also rejected. The Chi-square coefficients for the DISTRESS variable measured using Altman's Zscore, Hopwood's bankruptcy probability score and Zmijewski's bankruptcy probability score are $-5.04,5.23$ and 7.91 respectively, with each significant at the .01 level. Given the similar underlying financial data used by each of the three measures, and given the similar results when each of the variables is used in the regression equation, it is likely that the results of prior research studies are not significantly affected by the choice of which "distress" variable is used. This conclusion is consistent with Geiger and Raghunandan (2002), who initially use the Hopwood et al. (1994) bankruptcy probability score in their model, but also state, "As part of sensitivity tests, we also used the model from Zmijewski (1984) to calculate the probability of bankruptcy. The results remain essentially the same when this alternative model is used."

The logistic regression results related to Hypothesis 2 are presented in Table 3. Shown are the coefficients (Chi-square values in parentheses) for each of the variables in Model 2, including the "DISTRESS" variable measured using each of the three alternative measures for financial distress, and with the regression model calculated separately for the sample of firms both excluding and including "non-stressed" firms. Prior research studies have typically excluded non-stressed firms in their analysis, under the assumption that auditors generally do not issue going-concern audit opinions for non-stressed companies that suddenly fail and that other factors lead to 
the firm failure. Therefore, non-stressed firms are typically excluded from auditing research studies examining going-concern issues. However, the exclusion of these firms may cause a sample bias and can be considered a limitation of these studies. Therefore, this study addresses the research question: Does exclusion of "non-stressed" firms in prior studies affect whether the variable for financial distress is significant?

Table 2: Logistic Regression Results Using Alternative Measures of Financial Distress

\begin{tabular}{|c|c|c|c|}
\hline Model $^{1}:$ GC & $\mathrm{ESS}+\beta_{2} \mathrm{LNSL}+\beta$ & $\mathrm{RLAG}+\beta_{5} \mathrm{BIGN}+\beta 6 \mathrm{I}$ & $7 \mathrm{EXCH}$ \\
\hline & Logis & Alternative Measures of & Distress $^{2}$ \\
\hline Variable & Altman's Z Score & Hopwood, et. al. (1994) & Zmijewski, et. al. (1984) \\
\hline$\overline{\text { Intercept }}$ & 23.5971 & 7.6626 & 3.2554 \\
\hline & $(8.46) *$ & $(6.94) *$ & $(2.57) *$ \\
\hline DISTRESS & -28.8582 & 4.3439 & 14.6084 \\
\hline & $(-5.04) *$ & $(5.23) *$ & $(7.91) *$ \\
\hline LNSL & -.3010 & -.3589 & -.3779 \\
\hline & $(-6.36) *$ & $(-7.92) *$ & $(-8.67) *$ \\
\hline BLAG & -.1935 & -.1908 & -.1895 \\
\hline & $(-11.31) *$ & $(-11.24) *$ & $(-10.94) *$ \\
\hline RLAG & .0414 & .0366 & .0215 \\
\hline & $(1.28)$ & $(1.14)$ & $(.65)$ \\
\hline BIGN & -.3314 & -.3599 & -.2678 \\
\hline & $(-1.80)$ & $(-1.96) *$ & $(-1.43)$ \\
\hline DFLT & .3418 & .3958 & .3305 \\
\hline & $(1.40)$ & $(1.60)$ & $(1.31)$ \\
\hline $\mathrm{EXCH}$ & -.1153 & -.1321 & .0212 \\
\hline & $(-.69)$ & $(-.79)$ & $(.12)$ \\
\hline
\end{tabular}

$1 \quad$ Variables defined as:

$\mathrm{GC} \quad=\quad 1$ if audit report contained a going-concern opinion, 0 otherwise

DISTRESS $=$ Level of "financial distress" measured using either Altman's Z Score, Hopwood's (1994)

LNSL $=\begin{aligned} & \text { bankruptcy probability score, or Zmijewski's } \\ & \text { natural log of sales (in thousands of dollars) }\end{aligned}$

BLAG $=$ square root of the number of days from the audit report date to the bankruptcy date

RLAG = square root of the number of days from the fiscal year end to the audit report date

BIGN = 1 if audit firm was from the BigN, 0 otherwise

DFLT $=1$ if firm is in debt default, 0 otherwise

$\mathrm{EXCH}=1$ if firm is listed on NYSE or AMEX, 0 otherwise

2 Alternative measures of "Financial Distress" that are examined include:

- Altman's Z Score

- Hopwood, et al. (1994) bankruptcy probability score

- Zmijewski, et al. (1984) bankruptcy probability score

* Significant at the .05 level. Chi-square values in parentheses.

Table 3 presents the results from this analysis. Regardless of the DISTRESS variable that is used to measure financial distress, the significance of the DISTRESS variable is similar between the distressed sample and the full sample. In fact, the significance of each of the other variables in the model are also unaffected by the choice of either the distressed or the full sample. Thus, it is likely that the results of prior research studies are not significantly affected by the elimination of non-stressed firms from their samples. 
Table 3: Logistic Regression Results Using Alternative Measures of Financial Distress: Comparison of Results for Distress versus Full Sample

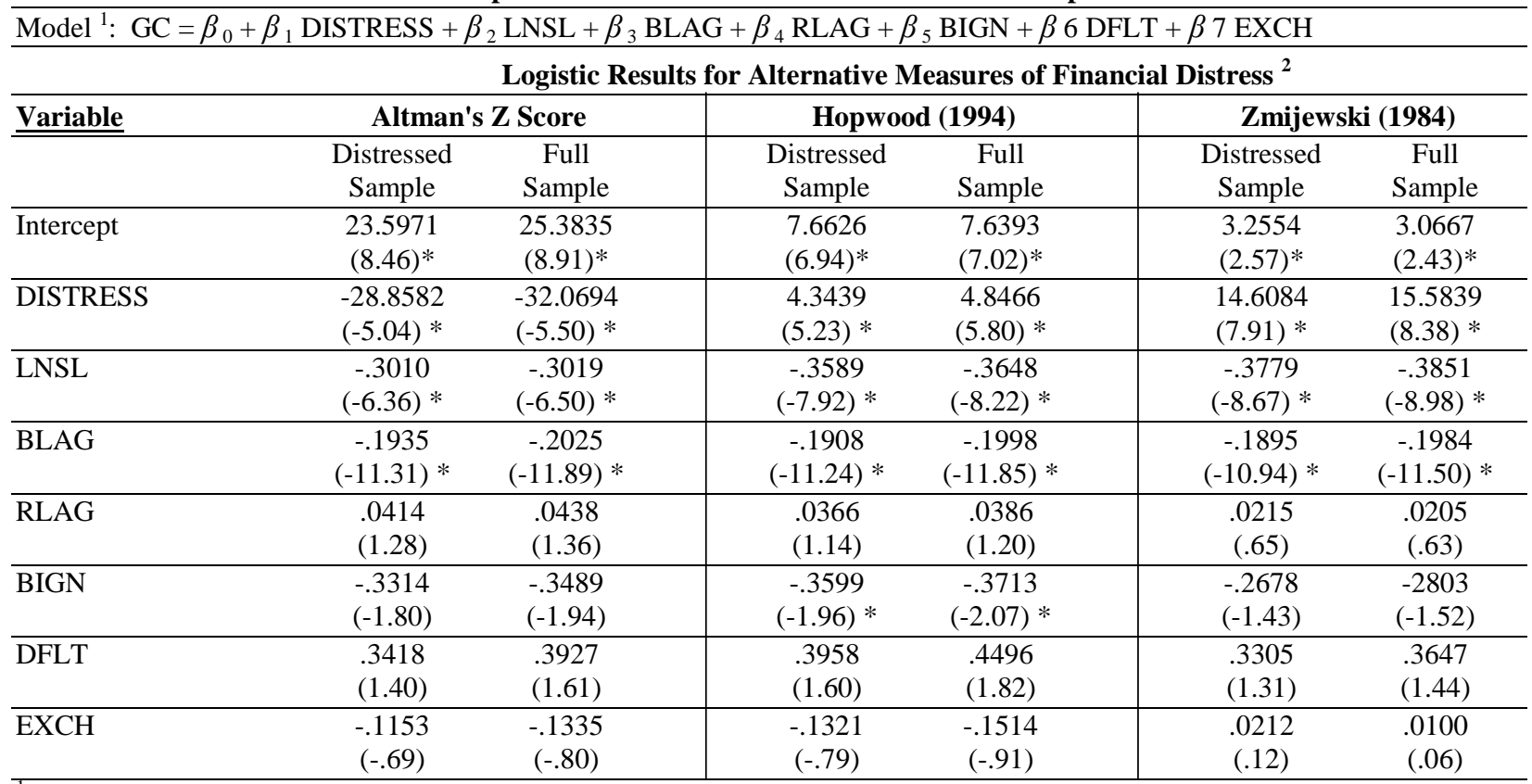

Tariables defined as:

$\mathrm{GC} \quad=\quad 1$ if audit report contained a going-concern opinion, 0 otherwise

DISTRESS $=$ Level of "financial distress" measured using either Altman's Z Score, Hopwood's (1994)

LNSL $=\begin{aligned} & \text { bankruptcy probability score, or Zmijewski's } \\ & \text { natural log of sales (in thousands of dollars) }\end{aligned}$

BLAG = square root of the number of days from the audit report date to the bankruptcy date

RLAG = square root of the number of days from the fiscal year end to the audit report date

BIGN $=1$ if audit firm was from the BigN, 0 otherwise

DFLT $=1$ if firm is in debt default, 0 otherwise

$\mathrm{EXCH}=1$ if firm is listed on NYSE or AMEX, 0 otherwise

2 Alternative measures of "Financial Distress" that are examined include:

- Altman's Z Score

- Hopwood, et al. (1994) bankruptcy probability score

- Zmijewski, et al. (1984) bankruptcy probability score

* Significant at the .05 level. Chi-square values in parentheses.

Our final research question, based on limitations of prior research, is: Does the effect of financial distress [i.e., the DISTRESS variable in model (2) above] remain linear and apply equally to all levels of financial distress? This is the assumption of prior research studies which have used a financial distress variable in their regression models. This assumption is illustrated in Figure 1 below. 


\title{
Figure 1
}

\author{
Assumption in Prior Studies: \\ Relationship Between the Level of Financial Distress and the Probability \\ of Receiving a Going Concern Audit Opinion
}

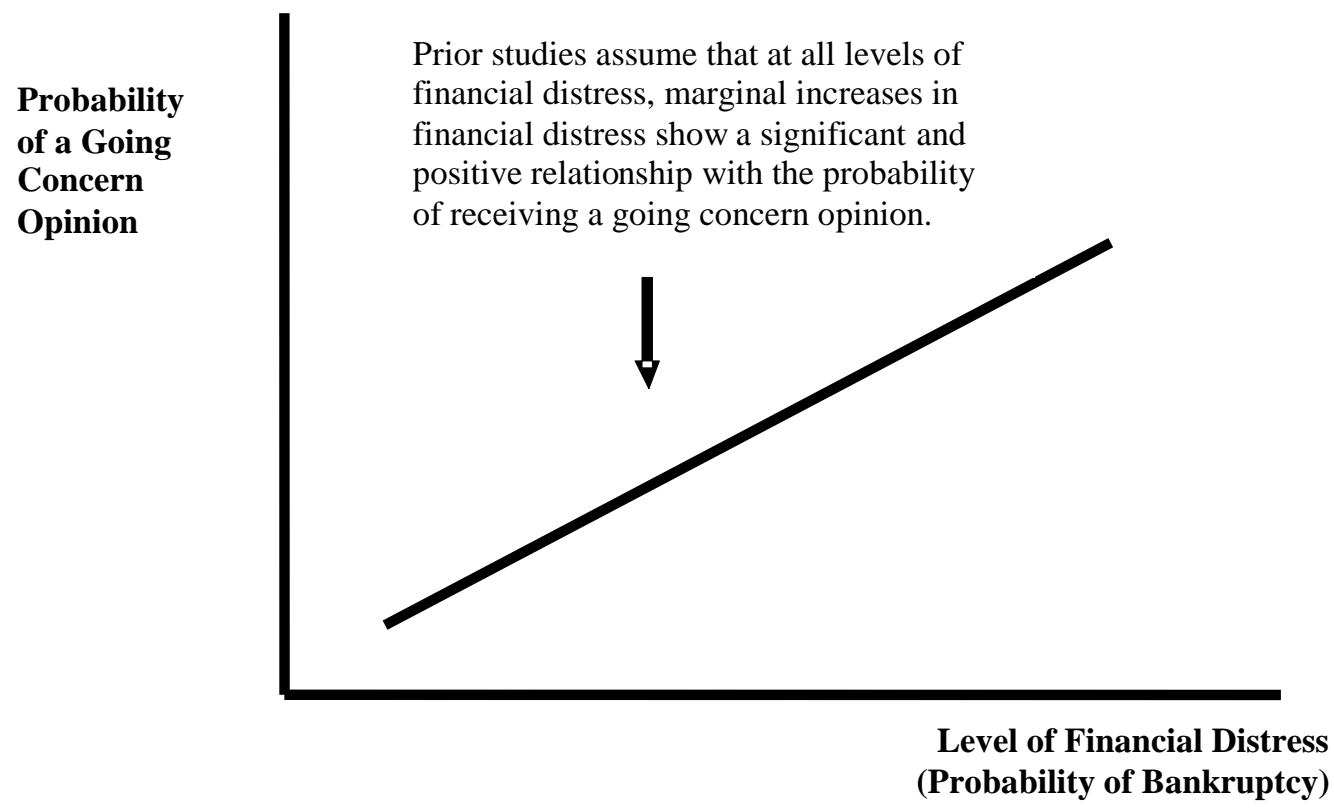

However, this assumption of a linear relationship between financial distress and the probability of receiving a going-concern audit opinion has weaknesses. First, prior research has already acknowledged that auditors generally do not issue going-concern opinions for non-stressed companies; Mutchler (1985), Hopwood et al. (1994), and Geiger and Rama (2006). Thus, at low levels of financial distress, one would expect no relationship between the level of financial distress and the likelihood of receiving a going-concern. Similarly, we would argue that once a firm reaches a certain upper level of financial distress and the auditor incorporates that information into their goingconcern decision, that further marginal increases in the level of financial distress would not marginally affect the auditor's decision to issue a going-concern.

In other words, we hypothesize that the relationship between financial distress and the probability of receiving a going-concern is not linear for all levels of financial distress. Rather, at higher levels of financial distress, it is hypothesized that financial distress has become fully reflected in the auditor's assessment of going concern, and that above a certain level, marginal increases in financial distress become unrelated to the probability of receiving a going-concern opinion. We illustrate this hypothesis in Figure 2 below. 
Figure 2

\author{
Hypothesis in Current Study: \\ Relationship Between the Level of Financial Distress and the Probability \\ of Receiving a Going Concern Audit Opinion
}

$\begin{aligned} & \text { Probability } \\ & \text { of a Going } \\ & \text { Concern } \\ & \text { Opinion }\end{aligned}$
distress, it is hypothesized that
financial distress is not
relevant, and that up to a certain
level, marginal increases show
no significant relationship with
the probability of receiving a
going concern opinion.

Level of Financial Distress
(Probability of Bankruptcy)

This hypothesis is addressed by examining whether the coefficient for the "DISTRESS" variable remains constant for all levels of distress, i.e., whether the relationship is linear. If it is not, then this would indicate that the relationship between financial distress and Type II audit errors depends on the underlying level of financial distress. Results for this analysis are presented in Tables 4, 5 and 6.

Table 4 presents the coefficients (Chi-square values in parentheses) for each of the variables in Model 2, measuring the DISTRESS variable using Altman's Z-score. The regression model was calculated separately for three different ranges of DISTRESS variable values; the lower $15 \%$ of DISTRESS values, the middle $70 \%$ of DISTRESS values, and the upper 15\% of DISTRESS values. Of interest are the Chi-square values for the DISTRESS coefficients for each of the three categories of DISTRESS values. For financial distress values in category 1 , (the lower $15 \%$ of DISTRESS values), the Chi-square value for the DISTRESS coefficient is -1.14 , and is not statistically significant. In other words, for lower levels of financial distress, there is no significant relationship between the level of financial distress and the probability of receiving a going-concern audit opinion. This is consistent with our hypothesis as described in Figure 2.

Similarly, for financial distress values in category 3, (the upper 15\% of DISTRESS values), the Chi-square value for the DISTRESS coefficient is .82, which is again not statistically significant, and is again consistent with our hypothesis as described in Figure 2. At higher levels of financial distress, the information about financial distress 
has become fully reflected in the auditor's assessment of going concern, and above a certain level, marginal increases in financial distress become unrelated to the probability of receiving a going-concern opinion. For the remaining levels of financial distress (Category 2 of the DISTRESS values in Table 4), the Chi-square value for the DISTRESS coefficient is -6.59 , significant at the .01 level. This is consistent with our earlier findings in Tables 2 and 3, and is also consistent with our hypothesis as described in Figure 2; that only within a certain range is financial distress positively and significantly related to the probability of receiving a going-concern audit opinion.

Table 4: Logistic Regression Results (Financial Distress Measured Using Altman's Z Score)

\begin{tabular}{|c|c|c|c|}
\hline \multicolumn{4}{|c|}{ Logistic Results for Various Levels of Financial Distress ${ }^{2}$} \\
\hline Variable & Category 1 & Category 2 & Category 3 \\
\hline \multirow[t]{2}{*}{ Intercept } & 15.5631 & 53.1311 & -.4756 \\
\hline & $(3.68) *$ & $(7.75) *$ & $(-.03)$ \\
\hline \multirow[t]{2}{*}{ DISTRESS } & -5.7243 & -89.2689 & 24.69 \\
\hline & $(-1.14)$ & $(-6.59) *$ & $(.82)$ \\
\hline \multirow[t]{2}{*}{ LNSL } & -.3401 & -.1747 & -.5813 \\
\hline & $(-1.91)$ & $(-3.35) *$ & $(-3.68) *$ \\
\hline \multirow[t]{2}{*}{ BLAG } & -.1264 & -.2033 & -.2501 \\
\hline & $(-2.17) *$ & $(-10.32) *$ & $(-4.39) *$ \\
\hline \multirow[t]{2}{*}{ RLAG } & -.2713 & .0589 & .0522 \\
\hline & $(-2.14) *$ & $(1.49)$ & $(.76)$ \\
\hline \multirow[t]{2}{*}{ BIGN } & -1.3015 & -.3949 & .2609 \\
\hline & $(-2.04) *$ & $(-1.85)$ & $(.49)$ \\
\hline \multirow[t]{2}{*}{ DFLT } & .2971 & .3237 & .2638 \\
\hline & $(.76)$ & $(1.23)$ & $(.22)$ \\
\hline \multirow[t]{2}{*}{$\mathrm{EXCH}$} & -.5702 & -.0095 & .0056 \\
\hline & $(-.67)$ & $(-.05)$ & $(.01)$ \\
\hline
\end{tabular}

I Variables defined as:

GC $=1$ if audit report contained a going-concern opinion, 0 otherwise.

DISTRESS $=$ Level of "financial distress" measured using Altman's Z Score.

LNSL $=$ natural log of sales (in thousands of dollars).

BLAG = square root of the number of days from the audit report date to the bankruptcy date.

RLAG = square root of the number of days from the fiscal year end to the audit report date.

BIGN = 1 if audit firm was from the BigN, 0 otherwise.

DFLT $=1$ if firm is in debt default, 0 otherwise.

$\mathrm{EXCH}=1$ if firm is listed on NYSE or AMEX, 0 otherwise.

2 The DISTRESS variable in the regression model was Altman's Z score.

The logit model was run separately for each of the three categories of scores:

Category 1: Lower 15 percent of DISTRESS values

Category 2: Middle 70 percent of DISTRESS values

Category 3: Upper 15 percent of DISTRESS values

* Significant at the .05 level. Chi-square values in parentheses.

Tables 5 and 6 present the coefficients (with related Chi-square values in parentheses) for each of the variables in Model 2, measuring the DISTRESS variable using Hopwood's (1994) model (shown in Table 5) and Zmijewski's (1984) model (shown in Table 6). Regardless of the measure used for financial distress, the results are again consistent: for both lower levels (Category 1) and upper levels (Category 3 ) of financial distress, there is no significant relationship between the level of financial distress and the probability of receiving a going-concern audit opinion. 
Table 5: Logistic Regression Results

(Financial Distress Measured Using Hopwood's (1994) Bankruptcy Probability Score) Model ${ }^{1}: \quad \mathrm{GC}=\beta_{0}+\beta_{1}$ DISTRESS $+\beta_{2}$ LNSL $+\beta_{3}$ BLAG $+\beta_{4}$ RLAG $+\beta_{5}$ BIGN $+\beta 6$ DFLT $+\beta 7$ EXCH

Logistic Results for Various Levels of Financial Distress ${ }^{2}$

\begin{tabular}{lccc}
\hline Variable & Category 1 & Category 2 & Category 3 \\
\hline Intercept & 7.7158 & 6.4086 & 4.5631 \\
& $(3.13)^{*}$ & $(4.01)^{*}$ & $(1.32)$ \\
\hline DISTRESS & .7474 & 9.7482 & 1.9859 \\
& $(.19)$ & $(5.14) *$ & $(.87)$ \\
\hline LNSL & -.2764 & -.4146 & -.0086 \\
& $(-2.30) *$ & $(-.07)$ \\
\hline BLAG & -.2186 & $(-7.36) *$ & -.0829 \\
& $(-4.83) *$ & -.2074 & $(-1.54)$ \\
\hline RLAG & -.0024 & $(-10.18) *$ & -.2190 \\
& $(-.04)$ & .0745 & $(-1.78)$ \\
\hline BIGN & -.0735 & $(1.81)$ & -2.3487 \\
& $(-.17)$ & -.3345 & $(-3.00) *$ \\
\hline DFLT & -.0332 & $(-1.52)$ & .3427 \\
& $(-.05)$ & .5002 & $(.89)$ \\
\hline EXCH & -.3754 & $(1.79)$ & .6337 \\
& $(-.93)$ & -.2370 & $(.97)$ \\
\hline
\end{tabular}

$1 \quad$ Variables defined as:

$\mathrm{GC}=1$ if audit report contained a going-concern opinion, 0 otherwise.

DISTRESS $=$ Level of "financial distress" measured using Hopwood's (1994) Bankruptcy Prob. Score.

LNSL $=$ natural log of sales (in thousands of dollars).

BLAG = square root of the number of days from the audit report date to the bankruptcy date.

RLAG = square root of the number of days from the fiscal year end to the audit report date.

BIGN $=1$ if audit firm was from the BigN, 0 otherwise.

DFLT $=1$ if firm is in debt default, 0 otherwise.

$\mathrm{EXCH}=1$ if firm is listed on NYSE or AMEX, 0 otherwise.

2 The DISTRESS variable in the regression model was Hopwood's (1994) Bankruptcy Probability Score.

The logit model was run separately for each of the three categories of scores:

Category 1: Lower 15 percent of DISTRESS values

Category 2: Middle 70 percent of DISTRESS values

Category 3: Upper 15 percent of DISTRESS values

* Significant at the .05 level. Chi-square values in parentheses.

\section{CONCLUSION}

Prior accounting research has examined variables associated with the likelihood of auditor's issuing a going-concern audit opinion for corporate clients that subsequently declare bankruptcy. This study has examined three limitations in that prior research related to how those studies measure "financial distress" and the assumptions in those studies related to the relationship between financial distress and the probability of receiving a going-concern audit opinion.

Using logistic regression, the current study examines the relationship between Type II audit errors and the level of financial distress. Results of this study: (a) address the limitations in prior research studies that have examined the relationship between financial distress and Type II audit errors, and, (b) provide evidence on the extent to which varying levels of financial distress affects the auditor's propensity to issue a going-concern audit opinion.

Specifically, we find that the relationship between financial distress and the probability of receiving a going-concern audit opinion is not linear, as is assumed in prior research studies. Rather, we find that at low levels of financial distress, financial distress is not relevant to the auditor's decision, and that marginal increases show no significant relationship with the probability of receiving a going-concern audit opinion. Similarly, we find that at 
higher levels of financial distress, the information about financial distress has already become fully reflected in the auditor's assessment of going-concern, and that above a certain level, marginal increases in financial distress become unrelated to the probability of receiving a going-concern opinion. These results have implications both in the interpretation of previous auditing research that has incorporated variables for financial distress, as well as implications for the design and interpretation of future research.

Table 6: Logistic Regression Results

(Financial Distress Measured Using Zmijewski's (1984) Bankruptcy Probability Score)

\begin{tabular}{|c|c|c|c|}
\hline \multicolumn{4}{|c|}{ Logistic Results for Various Levels of Financial Distress ${ }^{2}$} \\
\hline Variable & Category 1 & Category 2 & Category 3 \\
\hline \multirow{2}{*}{$\overline{\text { Intercept }}$} & 3.0636 & 2.7406 & 2.3762 \\
\hline & $(.56)$ & $(1.36)$ & $(.58)$ \\
\hline \multirow[t]{2}{*}{ DISTRESS } & 19.3651 & 19.4330 & 5.2965 \\
\hline & $(1.38)$ & $(5.52) *$ & $(1.43)$ \\
\hline \multirow[t]{2}{*}{ LNSL } & -.5339 & -.4244 & -.0791 \\
\hline & $(-4.33) *$ & $(-8.16) *$ & $(-.55)$ \\
\hline \multirow[t]{2}{*}{ BLAG } & -.2197 & -.2112 & -.0875 \\
\hline & $(-4.02) *$ & $(-10.43) *$ & $(-1.78)$ \\
\hline \multirow[t]{2}{*}{ RLAG } & .0044 & -.0018 & .0199 \\
\hline & $(.05)$ & $(-.05)$ & $(.08)$ \\
\hline \multirow[t]{2}{*}{ BIGN } & .5639 & -.4045 & -1.7733 \\
\hline & $(1.07)$ & $(-1.86)$ & $(-2.30) *$ \\
\hline \multirow[t]{2}{*}{ DFLT } & .3426 & .2478 & .2161 \\
\hline & $(.35)$ & $(.90)$ & $(.75)$ \\
\hline \multirow[t]{2}{*}{$\mathrm{EXCH}$} & .3537 & .0206 & .0824 \\
\hline & $(.54)$ & $(.11)$ & $(.13)$ \\
\hline
\end{tabular}

1. Variables defined as:

$\mathrm{GC} \quad=\quad 1$ if audit report contained a going-concern opinion, 0 otherwise.

DISTRESS $=$ Level of "financial distress" measured using Zmijewski's (1984) Bankruptcy Prob. Score.

LNSL $=$ natural log of sales (in thousands of dollars).

BLAG = square root of the number of days from the audit report date to the bankruptcy date.

RLAG $=$ square root of the number of days from the fiscal year end to the audit report date.

BIGN = 1 if audit firm was from the BigN, 0 otherwise.

DFLT $=1$ if firm is in debt default, 0 otherwise.

$\mathrm{EXCH}=1$ if firm is listed on NYSE or AMEX, 0 otherwise.

2 The DISTRESS variable in the regression model was Zmijewski's (1984) Bankruptcy Probability Score.

The logit model was run separately for each of the three categories of scores:

Category 1: Lower 15 percent of DISTRESS values

Category 2: $\quad$ Middle 70 percent of DISTRESS values

Category 3: Upper 15 percent of DISTRESS values

* Significant at the .05 level. Chi-square values in parentheses.

\section{AUTHOR INFORMATION}

Paul Wertheim, Ph.D., Professor of Accounting, Abilene Christian University. E-mail: paul.wertheim@acu.edu

Michael Robinson, Ph.D., Professor of Accounting, Baylor University. E-mail: Michael_Robinson@baylor.edu 


\section{REFERENCES}

1. $\quad$ Altman, E. "Financial Ratios, Discriminant Analysis and the Prediction of Corporate Bankruptcy." Journal of Finance. September, 1968, pp. 589-609.

2. Beaver, W.H. "Financial Ratios as Predictors of Failure." Journal of Accounting Research. Supplement, 1966, pp. 71-111.

3. Callaghan, J., M. Parkash, and R. Singhal. "Going-Concern Audit Opinions and the Provision of Nonaudit Services: Implications for Auditor Independence of Bankrupt Firms." Auditing: A Journal of Practice \& Theory. Vol. 28, No. 1. May, 2009, pp. 153-169.

4. Carey, P., M.A. Geiger, and B.T. O'Connell. "Costs Associated With Going-Concern-Modified Audit Opinions: An Analysis of the Australian Audit Market." Abacus. Vol. 44, No. 1, pp. 61-81.

5. Carey, P., S. Kortum, and R. Moroney. "Auditors' Going Concern Modified Opinions Post 2001: Increased Conservatism or Improved Accuracy." Working Paper. 2007.

6. $\quad$ Deakin, E.B. "A Discriminate Analysis of Predictors of Business Failure." Journal of Accounting Research. Spring, 1972, pp. 167-179.

7. DeFond, M., K. Raghunandan, and K. Subramanyam. "Do Non-Audit Service Fees Impair Auditor Independence? Evidence from Going Concern Audit Opinions." Journal of Accounting Research. Vol. 40, No. 4. September, 2002, pp. 1247-1274.

8. Fargher, N., L. Jiang. "Changes in the Audit Environment and Auditors' Propensity to Issue GoingConcern Opinions." Auditing: A Journal of Practice \& Theory. Vol. 27, No. 2. November 2008, pp. 5577.

9. Francis, G., and J. Krishnan. "Evidence on Auditor Risk-Management Strategies Before and After The Private Securities Litigation Reform Act of 1995." Asia-Pacific Journal of Accounting \& Economics. Vol. 9. 2002, pp. 135-157.

10. Geiger, M., and K. Raghunandan. "Bankruptcies, Audit Reports, and the Reform Act." Auditing: A Journal of Practice \& Theory. Vol. 20, No. 1. March, 2001, pp. 187-195.

11. Geiger, M., and K. Raghunandan. "Going-Concern Opinions in the "New" Legal Environment." Accounting Horizons. Vol. 16, No. 1. March, 2002, pp. 17-26.

12. Geiger, M., and D. Rama. "Audit Fees, Nonaudit Fees, and Auditor Reporting on Stressed Companies." Auditing: A Journal of Practice \& Theory. Vol. 22, No. 2. September, 2003, pp. 53-69.

13. Geiger, M., and D. Rama. "Audit Firm Size and Going-Concern Reporting Accuracy." Accounting Horizons. Vol. 20, No. 1. March, 2006, pp. 1-17.

14. Geiger, M., K. Raghunandan, and D. Rama. "Auditor decision-making in different litigation environments: The Private Securities Litigation Reform Act, audit reports and audit firm size." Journal of Accounting and Public Policy. Vol. 25. 2006, pp. 332-353.

15. Geiger, M., K. Raghunandan, and D. Rama. "Recent Changes in the Association between Bankruptcies and Prior Audit Opinions.” Auditing: A Journal of Practice \& Theory. Vol. 24, No. 1. May, 2005, pp. 2135.

16. Hopwood, W., J. McKeown, and J. Mutchler. "A Reexamination of Auditor Versus Model Accuracy Within the Context of the Going-Concern Opinion Decision." Contemporary Accounting Research. Spring, 1994, pp. 409-431.

17. Libby, R. "The Use of Simulated Decision Makers in Information Evolution." The Accounting Review. July, 1975, pp. 475-489.

18. Mutchler, J. "A Multivariate Analysis of the Auditor's Going-Concern Opinion Decision." Journal of Accounting Research. Vol. 23, No. 2. Autumn, 1985, pp. 668-682.

19. Myers, L., J. Schmidt, M. Wilkins. "Have Auditors Become Too Conservative? Evidence from Going Concern Opinions.” Working Paper. January, 2008.

20. Reynolds, J., and J. Francis. "Does Size Matter? The Influence of Large Clients on Office-Level Auditor Reporting Decisions." Journal of Accounting and Economics. Vol. 30. 2000, pp. 375-400.

21. Robinson, D. "Auditor Independence and Auditor-Provided Tax Service: Evidence from Going-Concern Audit Opinions Prior to Bankruptcy Filings." Auditing: A Journal of Practice \& Theory. Vol. 27, No. 2. November, 2008, pp. 31-54.

22. Zmijewski, M.E. "Methodological Issues Related to the Estimation of Financial Distress Prediction Models." Journal of Accounting Research. Supplement, 1984, pp. 59-82. 


\section{NOTES}

